\title{
Understanding Organizational Barriers Influencing Local Electronic Government Adoption and Implementation: The Electronic Government Implementation Framework
}

\author{
Nurdin Nurdin ${ }^{1}$, Rosemary Stockdale ${ }^{2}$, and Helana Scheepers ${ }^{3}$ \\ Swinburne University of Technology, Faculty of ICT, ${ }^{1}$ nnurdin@swin.edu.au, ${ }^{2}$ rstockdale@swin.edu.au, \\ 3 hscheepers@swin.edu.au
}

Received 30 July 2010; received in revised form 11 March 2011; accepted 11 April 2011

\begin{abstract}
Researches in electronic government have indicated a number of organizational barriers that hinder the adoption and implementation of electronic government. This paper proposes a research framework for analysing how organizational barriers influence the adoption and implementation of e-government at local levels. The framework is constructed based on four organizational dimensions; adaptability, involvement, mission, and bureaucracy drawn from organizational theories and e-government literature. We found that organizational barriers which are identified in major e-government literature link to the dimensions of organizational culture and effectiveness. Our conclusion is that the framework is relevant to understand organizational barriers influencing adoption and implementation of local e-government. The limitation of this study is that the framework has been developed based on the application of a theoretical lens on the e-government literature. It is now necessary to test this model in different contexts.
\end{abstract}

Keywords: E-government, Adoption, Implementation, Local government, Organizational barriers 


\section{Introduction}

Electronic government (e-government) is defined as the use of information and communication technology, particularly the Internet, as the means to improve government administration efficiency and deliver services to citizens, businesses, and other entities [13], [111]. The intention to implement e-government projects by government organizations has intensified as citizens' demand better services. The citizens' demand is triggered by experiences of the benefits of information technology implementation in private organizations which have resulted in similar benefits expectation from government organizations such as local governments [8], [52]. Consequently, information technology implementation in local government organizations needs to accommodate these expectations and demands. In other words, local governments are confronted with stakeholders' needs, such as citizens, companies, and higher levels of governmental organizations, to implement information technology in delivering better services and products [113].

However, e-government adoption and implementation is a challenging issue for many governments, particularly at local level, since many factors impede the implementations. These impeding factors includes technological [60], [97], financial [56], [63], and organizational constraints [58], [85]. These barriers have hindered the successful implementation of $85 \%$ of e-government systems, particularly in developing countries [54].

Several e-government studies indicate that there are many barriers related to the organizational constraints; for example unclear vision and strategy [8], [76], ambiguous missions and goals [15], [122], lack of coordination [65], [37], lack of partnership [10], organizational structure [53], and inappropriate change management [25]. These aspects have mainly been addressed in general terms without identifying how the barriers influence the adoption and implementation of e-government at organizational level, particularly at local government levels where the central governments might dictate the adoption and implementation process.

This study proposes a framework for understanding the influences of local e-government adoption and implementation from an organisational perspective. We integrate two well known organisational theories and apply them to local e-government adoption and implementation. We postulate that Denison and Mishra's theory on organisational culture and effectiveness is a useful starting point for understanding organizational barriers in local government organisations. The bureaucratic environment of e-government suggests that Wallach's dimension of bureaucracy is more appropriate than Denison and Mishra's dimension of consistency. Chen [16] argues that theory integration is suitable for building frameworks within specific contextual and situational conditions. This paper, therefore, attempts to answer the following research question:

How the organizational culture and effectiveness theory of Denison and Mishra [32], adapted with Wallach's [114] bureaucracy dimension, be integrated into a framework to explain organizational barriers influencing e-government adoption and implementation at local level?

This paper will address the above research question as follows. Section 2 discusses the current environment of electronic local adoption and implementation, while the link between organizational dimensions with organizational barriers is described in section 3. The next section identifies the barriers to e-government adoption and implementation from previous studies while section 5 validate the relationship of the organizational dimensions with organizational barriers in e-government adoption and implementation as well as we develop the framework to be applied in the study of the influence of organizational barriers to local e-government adoption and implementation. Finally, we discuss implications and future research directions and our conclusions.

\section{Electronic Local Adoption and Implementation}

In organisational context managers make the primary decision to adopt technology after identifying objectives to change aspects of the business [46]. A secondary adoption decision is made by individual employees to adopt the technology [46], [44]. This secondary adoption can either be mandated or voluntary depending on the context. In an e-government initiative there are similarities in that there are several levels of adoption: central government, local government, employees of local government and citizens. However, adoption within government is complicated by the political nature and structure of government [115]. The constitutional context of a government will determine the power of central government to mandate the adoption of technology at local level. Therefore the adoption of egovernment initiatives can be complex because "a government is an institution that holds the exclusive powers to enforce certain rules of social conduct in a given geographical area" [93].

For example, the UK government launched a modernization agenda in 1997 to transform local authorities' performance across the UK. This new agenda has resulted in the implementation of e-government at local level across the UK [8]. In a further step, the UK central government have set "e-government targets" which mandated all government agencies provide on-line interactions between government agencies and the public by 2005 [9]. Failure to conform to these policies and regulations can result in sanctions by central governments such as withdrawing funding that has been allocated to local governments [49]. Similarly, the adoption and implementation of the Smart 
Cards project in the medical sectors in Canada is mandatory [3]. These examples show that a central government has the power to impose the adoption of e-government on local government bodies by launching certain policies and regulations in order to improve governments' services.

Another example from a voluntary perspective, with support from top management, is the successful adoption of an e-government portal by government departments in Hong Kong [59]. The case of electronic tax managed by Central Excise in India is also voluntary and the citizens at local level are encouraged to adopt the system [98]. In both cases, the e-government initiatives are voluntarily adopted by lower levels although the initiatives are started at central level. However, in the case of Tanzanian's Integrated Tax Administration (ITAX), a part of e-government implementation [100], the project was mandatorily adopted by all tax regions of the country by 2007 . The initiative was controlled and supported by a task force authority at central government level.

From a grassroots level, in the United States the adoption of e-government at local levels was initiated before the EGovernment Act [11], [91] which included the planning of an e-government strategy and initiative implementation launched in 2002 [75]. This means the initiatives are developed on the basis of local government initiatives which are followed by government guidelines to support better implementation.

Many local governments have implemented e-government voluntarily or mandatorily to improve their organizational performance in serving the citizens but have failed to sustain the initiatives. Some e-local government projects have successfully achieved their goals in providing better services to the citizens for years but failed to sustain them over the long term such as the case of Tamil Nadu in India [72] and South Sulawesi local government in Indonesia [61].

The above examples of e-government initiatives are drawn together in Figure 1 to show the instances of voluntary and mandatory adoption from central government through to citizen.

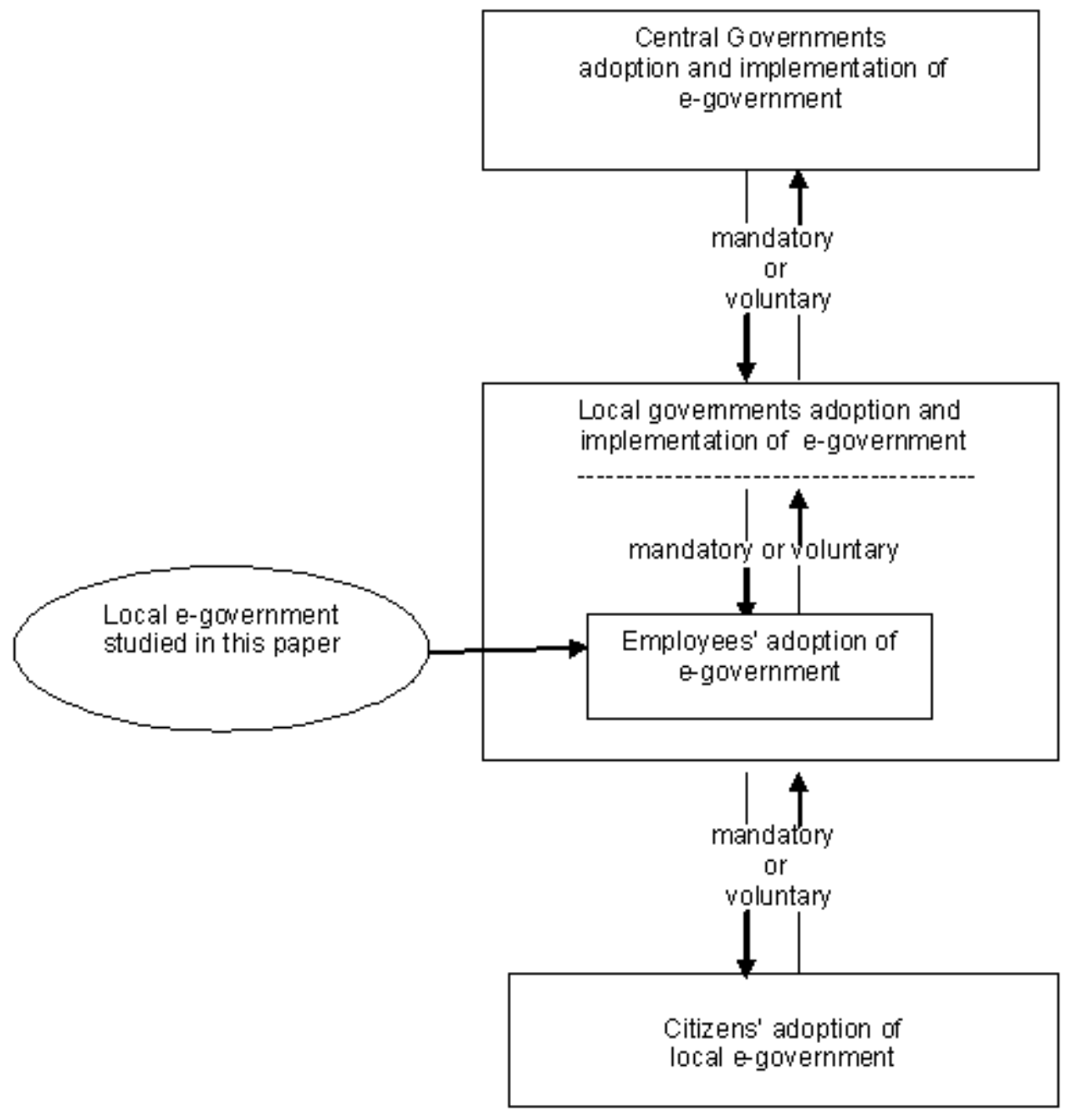

Figure 1: Electronic local government adoption strategy 
Even though local governments have made progress in implementing e-local government, the progress is slow [36]. For example, the movement toward integrated and transactional e-government is slower in developing countries than developed countries such as the United States [91]. Slow development of e-government is caused by many factors such as low commitment of local authorities, absence of coordination and support from central level government to help local government move to transactional or integrated stages of e-government implementation [68]. The majority of electronic local government in developing countries are at the web presence stage [60] in which their offerings are primarily basic information. It is not surprising that the majority of developing countries experience more failure in e-government implementation [65]. In none of the research identified has the role of the local government employee been identified and studied. The following sections address the barriers of e-government adoption and implementation at local levels.

\section{Linking Organizational Culture and Effectiveness to Organizational Barriers in E-government}

In the context of government organizations, one measure of the effectiveness of a government's performance is the result of the adoption and implementation of e-government [21], [45], [86], [89], [116]. Denison and Mishra's [32] model 'identifies cultural traits and values associated with effectiveness'. These cultural traits and values are organised into four dimensions: adaptability, involvement, mission and consistency. In their model they distinguish between internal integration and external adaptation. The former refers to the positive identification of the organisation's people with the organisation's interests. The latter refers to the ability of organisations to develop their capacity to change in response to external conditions and expectations. Denison and Mishra [32] also refer to stability and flexibility. Organisations, they argue, use the dimensions of mission and consistency to create stability, which plays an important role in achieving effectiveness. While mission provides people in the organisation with clear directions and meaning, consistency establishes norms that facilitate their conformity. On the other hand, the level of organisation's flexibility enables it to adapt to external factors, which will lead to a change in the organization's knowledge and behaviour. This ability is supported by internalized values and shared beliefs that allow people to get involve and commit to change [32].

Previous studies have used Denison and Mishra as a means of explaining the environment of technology adoption such as internet adoption in India [26], information systems implementation in Kenyan public universities [47], and technology adoption within the Australian health sector [99]. They do not however explore the cultural traits and values and their relationship with effectiveness. In an examination of organizational barriers that hinder the effectiveness of e-government initiatives, we have identified several that bear similarities with Denison and Mishra's cultural dimensions. Given that these dimensions are associated with effectiveness we propose that using the model for constructing a framework will enhance understanding of the complicated issues that surround the adoption and implementation of e-government at local level. The inclusion of internal and external factors in their model allow for the exploration of the complexity of the different constitutional contexts found in e-government adoption and implementation. These complexities include the role of people and their commitment to their organization and the role of external pressures that affect the organization's ability to achieve effectiveness.

Millard's [83] study into the measurement of e-government implementation effectiveness identified several organisational traits related to internal integration, such as the ability to reduce administrative burdens, improve user satisfaction and increase transparency. At the same time Millard refers to the external factors that can impede or enhance the adoption and implementation of e-government. These factors, which relate to Denison and Mishra's external adaptation include actions by consumers, other governments or public sectors and economic or market conditions.

Further justification towards the relation of barriers in e-government adoption and implementation with Denison and Mishra's [32] organizational cultural dimensions, shown in Table 1, are found in e-government studies that identify organisational barriers. For example, trust and people's skill in using the Internet have been associated with the culture to adopt e-government in the UK by Carter and Weerakkody [14]. Other factors identified include bureaucracy and management [23], hierarchy [79], mission, vision and goal [81], commitment [96], and transparency [90], [7].

We propose that a framework based on the four organizational cultural dimensions developed by Denison and Mishra [32] will shed light on the effective adoption and implementation of e-government by local government organizations. However, we do not adopt the fourth organizational dimension, consistency, as proposed by Denison and Mishra. In previous research consistency has been renamed bureaucracy [47] without a careful consideration of the factors associated with bureaucracy. We develop the factors of bureaucracy as identified by Wallach [114] that refer to explicit rules, regulations, and hierarchies in an organization, which is typical of government organizations [4] A more detailed discuss is provided in Section 3.4 to outline the implication of replacing consistency [32] with bureaucracy [114] 
Table 1: Organizational dimensions and relevant issues included

Organizational Dimensions

1. Involvement

2. Adaptability

3. Mission

4. Bureaucracy

\section{Factors}

\author{
Participation \\ Commitment \\ Partnership \\ Responsibility
}

Change Management

Transparency

Trust

Organizational learning

Vision
Goal
Strategy

Hierarchy/Structure

Regulation

Coordination

\subsection{Involvement}

Involvement is organizational values that support members of an organization gain a sense of responsibility, and commitment in the organization through their involvement in an organization's activities [32]. Barki and Hartwick [51] defines involvement as a subjective psychological state of users which is found in participative behaviour and activities performed. Denison and Mishra add that when people in the organization are highly involved, the organization is more productive because they are more committed and responsible towards the organizations' interest. But when the organization experiences a lack of involvement by people in tasks, it is difficult to respond to critical environmental change.

In studies of e-government adoption and implementation researchers refer to involvement by citizens and government employees. In this paper, however, we will only focus on the government employees and government institution involvement. Their involvement is shown in context of their willing to participate, build partnership, improve commitment, and take maximum responsibility in adoption and implementation of e-government initiatives. Involvement of all employees and government institutions will affect the success of system development adoption in a public organization. For example, the wide range of participation in e-stamping adoption in Hong Kong has contributed to its successful implementation [78]. On the other hand, low involvement can resulted in a lack of users' participation, commitment, and responsibility during information systems development because users' beliefs and attitude which are associated with their psychological need to be involved are not clearly formed toward the adopted system [51].

High participation of people through partnership building can enhance adoption and implementation because the high level of collaboration by people will increase the level of acceptance and increase the quality as well as preventing conflict [101]. Partnership among local public administrations, for example, can benefit for reducing cultural impediment and enhance effective resource allocation in diffusing e-government [43]. High level of collaboration and partnership in adoption and implementation of e-government might also result in establishing high value of responsibility and commitment to support the success of e-government project, as seen in a study of egovernment adoption in Singapore [107]. This may include highly committed leaders with strong leadership who want to take real responsibility in facilitating a successful e-government adoption [78]. Leaders show their commitment through their involvement by viewing information technology as a critical success factor for their organizations [66] and this active commitment from top management has been seen, such as in Florida and Texas cities, as an important e-government adoption enhancer [94] .

\subsection{Adaptability}

Adaptability focuses on the demands of the external situation and the influence of norms and beliefs that support an organization's capacity to respond to the need for change [32]. In other words, an organization's adaptability is driven by demands or needs from outside the organization [30]. Community expectations and demands often become a basis for governments in implementing new innovation in their organizations such as the demand of citizens for technology based services that enable them to access government services $24 / 7$. When more and more businesses

Nurdin Nurdin Rosemary Stockdale Helana Scheepers 
and other private organizations offer effective and efficient electronic services, citizens also expect the same from their local government [22]. In response to this demand, government organizations adapt their services to the new expectations from their communities.

The organization's adaptability involve element of change [12]. In context of e-government implementation, change management is considered as a continual process which increase the usability of e-government system [106]. This means government organizations established new management strategy which is compatible to the new work systems such as improving internal transparency, building trust within organizations, and enhancing organizational and employees learning in response to external demands.

The transparency is practiced by organizations not only to their surroundings but also to themselves [19] and it is their endeavour to adapt their environment through openness to all stakeholders. In government organizations, openness includes good will to communicate details of systems and decision making to external observers [84]. Openness might also include the wiling of government organizations to provide information to all stakeholders in complying with the freedom of information policy [104], [64] such as making government information available online in open format [82]. The willingness of organizations to be transparent can enhance trust building between people inside the organizations and external stakeholders and, as a result, contributes to organization responsiveness to their environment.

Trust can create and enhance positive conditions, such as positive interpretation of another's behaviour, which enhance cooperation at group level and raises an organization's performance [118]. Another positive impact is that the cohesion and collaboration between people is facilitated by the presence of the trust value [80]. As the result, collective action of people can be generated and maintained in performing organizational tasks. In addition, when the value of trust is perceived among internal organization, the organizational risk toward innovation implementation is diminished as people are unlikely to perceive the innovation as a risk to them.

In e-government adoption and implementation, organizational adaptability toward environment expectation can also be established through organizational learning such as learning from other failure or learning from the mistakes they make during the adoption and implementation of e-government initiative [2], [53], [55]. Failure can be conceived as a value that provides opportunities to learn what is applicable and what is not applicable in a new system inside their organization through the sharing of information between local governments such as information on technology provider for e-government implementation [22]. Looking at other local government organizations can also help a local government identify the best actions to be taken in delivering high performance e-government. During the learning process, local governments can obtain positive values from other successful local e-governments adoption and then implement it in their environment.

\subsection{Mission}

Mission is an organization dimension that provides purpose and meaning to the organization and also gives direction and identifies goals that enable an organization to act in an appropriate way [32]. The organization establishes the mission as an instrument based on the managerial ethos and ideology of the organization and it therefore influences the development of the organization [40]. From the mission statement the organization acquires purpose and meaning as it defines social roles in the organization and designates roles of employees as related to the organization's role [32]. Clearer mission statements also help organizations' members understand why their organizations exist, what they do, and for whom they do it. The mission is transformed into vision and goals that enable organizations to operate them.

In e-government implementation, the existence of clear mission, vision, and goals during the adoption and implementation process is important to maintain organization's future directions. The mission and vision can be exhibited by top leaders who inspire a mindset change through government agencies to raise understanding about how importance the transformation of government into e-government is [69]. There are evidence that indicate that successful e-government implementation relate to clear organisational mission, visions, and objectives such as in the UK [42], Singapore [105] and Sragen local government in Indonesia [41]. It is a good strategy if clear visions are stated during pre e-government implementation activities to enhance organizational readiness [103].

On the other hand, unclear mission, visions, and goals might constrain implementation initiatives, for example the implementation of local municipal web site in California had resulted in low benefit for supporting local government economy and tourist development because of the lack of mission and vision during implementation [88]. Lack of mission and vision in e-government implementation might create disorientation of the project because government organizations and its employees might do not understand where the initiative is going and what it is trying to gain. As a result, the project implementation might not achieve it goals and produce significant benefit to the implementer.

In certain case, e-government implementation has also encountered uncertainty since the government goals to implement the initiatives is not well defined or the goals might conflict with other government project [28] or government officials are unable to align between the goals to implement e-government with their organizations and the main goal in serving their citizens such as in the case South Korea as identified by Kim \& Kim [70]. Goals problematic in e-government implementation can lead to difficulties in determining a strategy on how to implement

Nurdin Nurdin Rosemary Stockdale Helana Scheepers 
effective e-government systems because their orientation and objective are not clear. For example, how do horizontal and vertical or back and front office should be integrated and what benefits and who will benefit from the systems [1].

\subsection{Consistency versus Bureaucracy}

Consistency is "the values and behaviours that create alignment across the organization" [29] and it is an implicit control system based on shared belief of people within organizations. Denison and Mishra [32], [31] argues that implicit control systems based on internalized values can become a more effective means to achieve internal integration and coordination than explicit rules and regulations. Denison and Mishra [32], [31] add that people within organizations are able to reach consensus across level organizations and perform coordinated action through shared values and beliefs that, then, produce more positive impact on organizations compare to organizations managed with explicit rules. In other words, governance systems of organizations are created based on consensual support rather than rely on explicit rules and regulations [29].

Aucoin [4] argues that one characteristic of government organizations is that they are governed and managed with explicit rules, regulations, structures and hierarchies. It seems Denison and Mishra's [32] perspective is not compatible with government organizations environment in which this research intend to apply the perspective to study barriers influence in e-government adoption and implementation. Consequently, this research looks at another perspective which is relevant to government organizations. One perspective that is most suitable to a government organization is proposed by Wallach [114] ; bureaucracy.

Bureaucracy refers to the characteristics of an organization with clear lines of responsibility and authority based on control and power [114]. Wallach [114] argues that effective organizations are managed with explicit rules, hierarchical, cautious and solid, and their people work in a systematic and an organized way in an environment where responsibility and authority are clear. In a bureaucratic organization, such explicit regulations are formalized which means rules, procedures, norms, standards of behaviour, and communication are explicitly stated [62]. Bureaucracy also includes channels that guide actions and numbers of hierarchical levels within an organization [48]. Therefore, Aucoin [4] argues that bureaucracy is a significant element to support capable public management and good governance.

The presence of bureaucratic organizations in the public sectors will also benefit the process of an innovation implementation because clear and explicit regulations, standardization, and hierarchies support supervision to reduce the chance of errors, disobedience, and negligent behaviour among people. As the result, the bureaucracy which is embedded in government action intrinsic values can maintain the harmony public policies implementation because clear legal principles and procedures are enforced [24]. The nature of bureaucracy underpins the effort a government organization and its people undertake to achieve their goals to adopt and implement e-government through a structure of conformity to the regulations. This includes a bureaucratic leader who able to ensure the employees to put e-government initiatives implementation on a high priority [95]. The solidity of government organizations, based on clear regulations and hierarchies, create a sense of responsibility to succeed in the adoption and implementation of government initiatives. For example, Electronic Record Management Systems (ERMS) in Pakistan local governments has implemented successfully because the clear strong hierarchy in government administration and a clear distribution of tasks among employees [57].

The absence of a bureaucracy nature in government organizations might lead to weak coordination and unsuccessful government initiative implementation. For example the implementation of Government Electronic Administration (GEA) in Iran has not been as successful as expected because the government organizations are not well-organized and coordinated as well as the structure and organizations bodies are in dispute over their responsibilities towards the implementation [102].

\section{Barriers to E-government Adoption and Implementation}

We have detailed the argument for relating Denison and Mishra's [32] organisational dimensions of effectiveness to the barriers of e-government adoption and implementation. In this section we review the barriers identified in the egovernment literature, which we then relate to the Denison and Mishra model in Section 5.1.

Ebrahim and Irani [35] and Lam [74] have summarised barriers to e-government adoption and implementation from several perspectives; infrastructure, technological and organisational. Table 2 combines the literature found in Ebrahim and Irani [35] and Lam [74] with other sources that deal with organizational barriers to e-government adoption and implementation. 
Table 2: Organizational barriers in adoption and implementation of e-government

\begin{tabular}{|c|c|}
\hline Barriers & Authors \\
\hline $\begin{array}{l}\text { Lack of participation - citizens, political and internal government } \\
\text { users participation }\end{array}$ & [92], [71], [34] \\
\hline $\begin{array}{l}\text { Low commitment } \quad-\text { government leaders and } \\
\text { employees commitment }\end{array}$ & [76], [65], [38] \\
\hline $\begin{array}{l}\text { Lack of partnership/collaboration - partnership or } \\
\text { collaboration among local governments, inter-departments and } \\
\text { among employees }\end{array}$ & [89], [17], [39], [119] \\
\hline $\begin{array}{l}\text { Lack of responsibility - responsibility of government } \\
\text { Leaders, officials and ICT management }\end{array}$ & [65], [81], [105], [120] \\
\hline $\begin{array}{l}\text { Inadequate or no change of management } \\
\text { Strategy - change management strategy according to } \\
\text { new way of doing government business }\end{array}$ & [54], [25], [36] \\
\hline $\begin{array}{l}\text { Lack of transparency - transparency in management, } \\
\text { decision making and administration }\end{array}$ & [89], [17] \\
\hline $\begin{array}{l}\text { Lack of trust - trust between employees and } \\
\text { government institutions }\end{array}$ & [52], [71] \\
\hline $\begin{array}{l}\text { Lack of organizational/employees learning - governments do not } \\
\text { learn from other governments' experience and do not provide training } \\
\text { for employees. Employees do not have skills to use technology }\end{array}$ & [22], [2], [53], [55], [87], [112] \\
\hline $\begin{array}{l}\text { Unclear mission and visions - mission and visions are unclear or } \\
\text { not stated before e-government implementation }\end{array}$ & [76], [122] \\
\hline $\begin{array}{l}\text { Conflict or unclear of goals - goals to implement e-government are } \\
\text { unclear, not stated or they conflict with central government (local } \\
\text { government goals) or with other government projects implementation }\end{array}$ & $\begin{array}{l}{[122],[37],[28],[70],[27],[5],} \\
{[108]}\end{array}$ \\
\hline $\begin{array}{l}\text { Lack of implementation strategy - strategy formulation does not } \\
\text { include planning and strategy to align front office with back office of } \\
\text { e-government }\end{array}$ & {$[1],[18]$} \\
\hline $\begin{array}{l}\text { Restrictive law and regulations - no formal rules and regulations to } \\
\text { regulate e-transactions or data sharing }\end{array}$ & $\begin{array}{l}\text { [28], [17], [112], [27], [50], [77], } \\
{[109]}\end{array}$ \\
\hline $\begin{array}{l}\text { Rigid organization structure/hierarchy - organization structure and } \\
\text { hierarchy are not reformed and impede service integration and } \\
\text { administrative processes as well as delaying services }\end{array}$ & [53], [112], [109], [121], [73] \\
\hline $\begin{array}{l}\text { Weak coordination - coordination between central and local } \\
\text { government, between departments and employees. }\end{array}$ & [65], [37], [102], [11], [110], [6] \\
\hline
\end{tabular}

The barriers summarized above have been empirically found in many e-government adoption and implementation projects. For example, the e-government project in Tamil Nadu India was successfully adopted and implemented when the first public leader showed high commitment and support toward the Sustainable Access in Rural India (SARI) project implementation. However, when the new leader who replaced him failed to show the same level of leadership, commitment and support, the project development floundered [72].

A further example is the implementation of e-government in Zambia that has been challenged by the lack of coordination between government agencies, lack of commitment among government officials, and an unclear implementation strategy that have resulted in impeding the e-government implementation [17]. Lack of coordination might impede the clarity of responsibility sharing in the project implementation, particularly the coordination between government agencies or between local and state governments. Similarly, implementation of e-government in Jordan has experienced significant challenges because of the unclear responsibilities of the various actors involved in the project [20].

In some African countries, rigid government structures and hierarchy has been found to be another challenge that affects e-government implementation [53]. Rigid government structure and hierarchy hinder the change management that government organizations need to undergo. In fact, e-government requires a new environment in which it is able to adapt and sustain over a long period of time. This does not occur in African countries during adoption of the technology [55]. Failure of the e-government implementation is rampant among those countries

\section{Developing the Framework}

In this section, we will validate the relationship between the four organizational dimensions and the barriers identified in e-government studies. The relationships are validated through the linking of the factors with barriers found in egovernment studies (see Tables 1 and 2). The framework is then developed.

Nurdin Nurdin Rosemary Stockdale Helana Scheepers 


\subsection{The Relationship of Organizational Dimensions to the Barriers in E-government Adoption and Implementation}

Table 3 shows the organizational dimensions and factors (Denison and Mishra, 1995), as related to the barriers identified in the e-government literature.

Table 3: Relationship between organizational dimensions and the barriers in e-government

\begin{tabular}{|c|c|c|}
\hline $\begin{array}{c}\text { Organizational Dimensions } \\
\text { and } \\
\text { Factors Included }\end{array}$ & $\begin{array}{c}\text { Barriers in } \\
\text { E-government }\end{array}$ & $\begin{array}{c}\text { Barriers in } \\
\text { E-government: Sources }\end{array}$ \\
\hline $\begin{array}{l}\text { 1. Involvement } \\
\text { - Participation } \\
\text { - Commitment } \\
\text { - Partnership } \\
\text { - Responsibility }\end{array}$ & $\begin{array}{l}\text { - Lack of participation } \\
\text { - Lack of commitment } \\
\text { - Lack of collaboration or partnership } \\
\text { - Lack of responsibility among employees }\end{array}$ & $\begin{array}{l}\text { [92], [71], [34] } \\
\text { [76], [65], [38] } \\
\text { [89], [17], [39], [119] } \\
\text { [65], [81], [67], [120] }\end{array}$ \\
\hline $\begin{array}{l}\text { 2. Adaptability } \\
\text { - Change management } \\
\text { - Transparency } \\
\text { - Trust (employees \& inter } \\
\text { government institutions) } \\
\text { - Organizational/employee } \\
\text { learning }\end{array}$ & $\begin{array}{l}\text { - In adequate or no change management } \\
\text { - Lack of transparency } \\
\text { - Lack of employees trust or inter government } \\
\text { organizations trust. } \\
\text { - Lack of organizational and employees learning }\end{array}$ & $\begin{array}{l}\text { [54], [25], [36] } \\
{[89],[122]} \\
\text { [52], [71] } \\
{[22],[2],[53], \quad[55], \quad[87],} \\
{[112]}\end{array}$ \\
\hline $\begin{array}{l}\text { 3. Mission } \\
\text { - Vision } \\
\text { - Goal } \\
\text { - Strategy ( to achieve the } \\
\text { mission) } \\
\end{array}$ & $\begin{array}{l}\text { - Ambiguous or no mission or vision } \\
\text { - Unclear or no goals } \\
\text { - No or unclear strategies }\end{array}$ & $\begin{array}{l}\text { [76], [122] } \\
{[37],[28],[70],[27],[5]} \\
{[1],[18]}\end{array}$ \\
\hline $\begin{array}{l}\text { 4. Bureaucracy } \\
\text { - Regulations } \\
\text { - Organization Hierarchy/ } \\
\text { structure } \\
\text { - Coordination (vertical } \\
\text { and horizontal) }\end{array}$ & $\begin{array}{l}\text { - No regulations that support the e-government } \\
\text { implementation } \\
\text { - Unclear organization hierarchy or structure } \\
\text { - Weak or no coordination between employees or } \\
\text { government institutions. }\end{array}$ & $\begin{array}{l}\text { [28], [17], [112], [27], [50], } \\
\text { [77], [109] } \\
{[53],[112],[109],[121],} \\
{[73]} \\
{[65],[37],[102],[11],[110],} \\
{[6]}\end{array}$ \\
\hline
\end{tabular}

Our approach and assumption in linking the barriers in e-government adoption and implementation to Denison and Mishra's [32] and Wallach [114] organizational culture dimensions relies on theory building through identifying relationships between properties as proposed by Dubin [33]. Dubin [33] states that a characteristic of a thing can be determined by the relation among properties, either by interaction or by combination. We have provided evidence that the barriers can be combined with the factors of the dimensions. As the result, each barrier is placed accordingly within the organizational dimensions to provide greater understanding on how they are intertwined each other.

For example organizations adaptability is determined by an organization's ability to take action in accordance with their environmental expectations such as the presence of new technology, new working systems, and citizens' demand. The actions that can be taken to deal with adaptability might include change of management strategy, establishing trust among employees and departments as well as with their stakeholders, and improving transparency. Adaptation within the new environment also requires an organization's capability to adjust, which can be achieved through organizational and employee learning.

\subsection{The Proposed Framework}

The above discussion on organizational culture theory and barriers in e-government adoption and implementation is summarised in the following framework as depicted in Figure 2 which is designed to understand the barriers in a specific context of e-government adoption and implementation at local government. The framework reflects the majority of issues surrounding barriers in e-government adoption and implementation in local government organizations. The four organizational dimensions and the issues are often addressed in major e-government implementations. They might influence the effectiveness of e-government adoption and implementation at local government levels.

The relationship between local government and central government is also visualized in the framework to enable greater insight into external pressures, which affect coordination and conflict of mission between central and local governments. For example, the mission dimension, which involves vision, goals, and strategy of e-government implementation should be studied in the context of a local government's relationship with central government. This 
means the mission to adopt and implement e-government at local level might or might not be aligned with national mission, vision, goals and strategy in serving the citizens.

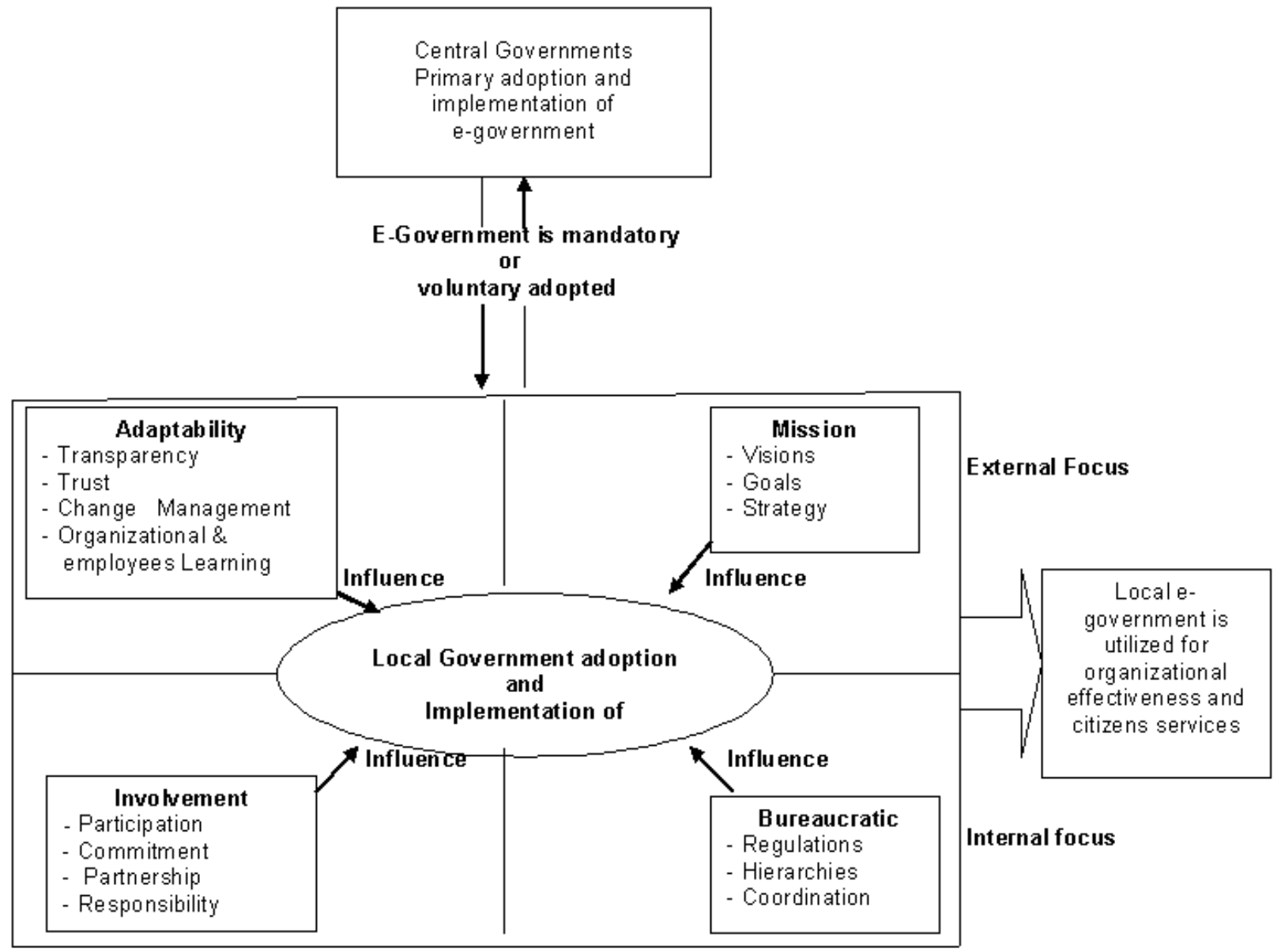

Flexible

Stable

Figure 2: The electronic government implementation framework adapted from [32] and [114]

\section{Implications and Future Research}

Scientifically, studying human and social phenomenon can be carried out through predicting and understanding [33]. This research is categorized in developing understanding of organizational barriers in information technology adoption and implementation of e-government systems. Particularly, the understanding of how the organizational dimensions and the factors in each dimensions impede the adoption and implementation of local e-government in an organizational context.

The proposed framework is an overview of barriers indicated in e-government studies and they are classified into four organizational dimensions. The framework is applicable to an information technology implementation in the context of organizations and the people relationship in local government organizations because it incorporates the interplay relationship between central and local government. The framework can be applied in the context of mandatory or voluntary implementation of local e-government. As a result, context-based and empirical knowledge can be gained across local e-government adoption and implementation issues to develop better understanding for academics and practitioners.

The limitation of this study is that the framework has been developed based on the application of a theoretical lens on the e-government literature. It is now necessary to test this model in different contexts. Examples of potential contextual differences are between developed and developing countries local government initiatives. For example, Chen, et al [17] identify issues such as regulations and transparency that might differ across countries. In addition, since the proposed framework is developed based on organizational theories, there might be some factors in the framework that are not considered as culturally related issues. 


\section{Conclusions}

This paper shows the link between the four dimensions of effective organisational culture and the barriers to egovernment adoption and implementation. This leads us to propose a framework which is constructed from the organizational theories of Denison and Mishra [32] and Wallach [114] to understand organizational barriers influencing adoption and implementation of local e-government. In addition, our proposed framework includes the role of central government in the mandatory or voluntary adoption of local e-government.

Adoption and implementation of e-government at local levels is a continuing and challenging process that involves many organizational constraints. A clear framework to understand the constraints influencing the implementation of local e-government is required to improve effectiveness. Therefore, our proposed framework is offered as a means to increase understanding of adoption and implementation of local e-government.

\section{References}

[1] K. V. Andersen and H. Z. Henriksen, E-government maturity models: Extension of the Layne and Lee model, Government Information Quarterly, vol. 23, no. 2, pp. 236-248, 2006.

[2] R. D. Atkinson, Digital government: The next step to reengineering the federal government, in Progressive Policy Institute, Washington, DC, 2000.

[3] B. A. Aubert and G. Hamel, Adoption of smart cards in the medical sector: The Canadian experience, Social Science \& Medicine, vol. 53, no. 7, pp. 879-894, 2001.

[4] P. Aucoin, The design of public organizations for the $21^{\text {st }}$ century: Why bureaucracy will survive in public management, Canadian Public Administration, vol. 40, no. 2, pp. 290-306, 1997.

[5] S. Basu, E-government and developing countries: An overview, International Review of Law, Computers \& Technology, vol. 18, no. 1, pp. 109-132, 2004.

[6] V. Bekkers and V. Homburg, The myths of e-government: Looking beyond the assumptions of a new and better government, Information Society, vol. 23, no. 5, pp. 373-382, 2007.

[7] C. Bertot, P. T. Jaeger, and J. M. Grimes, Using ICTs to create a culture of transparency: E-government and social media as openness and anti-corruption tools for societies, Government Information Quarterly, vol. 27, no. 3, pp. 264-271, 2010.

[8] P. Beynon-Davies and S. Martin, Electronic local government and the modernization agenda: Progress and prospects for public service improvement, Local Government Studies, vol. 30, no. 2, pp. 214-229, 2004.

[9] P. Beynon-Davies and M. D. Williams, Evaluating electronic local government in the UK, Journal of Information Technology, vol. 18, no. 2, pp. 137-149, 2003.

[10] M. M. Brown, L. J. O'Toole, and J. L. Brudney, Implementing information technology in government: An empirical assessment of the role of local leadership, Journal of Public Administration Research and Theory, vol. 8, no. 4, pp. 499-525, 1998.

[11] J. Burn and G. Robins, Moving towards E-government: A case study of organizational change process, Logistics Information Management, vol. 16, no. 1, pp. 25-35, 2003.

[12] K. M. Carley and D. M. Svoboda, Modeling organizational adaptation as a simulated annealing process, Sociological Methods \& Research, vol. 25, no. 1, pp. 138-168, 1996.

[13] L. Carter and F. Belanger, The utilization of e-government services: Citizens trusts, innovation and acceptance factors, Information Systems Journal, vol. 15, no. 1, pp. 5-25, 2005.

[14] L. Carter and V. Weerakkody, E-government adoption: A cultural comparison, Information Systems Frontiers, vol. 10, no. 4, pp. 473-482, 2008.

[15] T. Che-Wee, L. P. San, and T. K. L. Eric, Managing stakeholder interest in e-government implementation: Lessons learned from a Singapore e-government project, Journal of Global Information Management, vol. 13, no. 1, pp. 31-53, 2005.

[16] C. P. Chen, Integrating perspectives in career development theory and practice, The Career Development Quarterly, vol. 51, no. 3, pp. 203-216, 2003.

[17] Y. N. Chen, H. M. Chen, W. Huang, and R. K. H. Ching, E-government strategies in developed and developing countries: An implementation framework and case study, Journal of Global Information Management, vol. 14, no. 1, pp. 23-46, 2006.

[18] Y. Chien-Chih, A value-based strategic management process for e-government strategy planning and performance control, in Proceedings of the $1^{\text {st }}$ International Conference on Theory and Practice of Electronic Governance, Macao, China, 2007, pp. 169-178.

[19] L. T. Christensen, Corporate communication: The challenge of transparency, Corporate Communications: An International Journal, vol. 7, no. 3, pp. 162-168, 2002.

[20] C. Ciborra and D. D. Navarra, Good governance, development theory, and Aid policy: Risks and challenge of egovernment in Jordan, Information Technology for Development, vol. 11, no. 2, pp. 141-159, 2005.

[21] C. Codagnone and T. A. Undheim. (2008, August) Benchmarking e-government: Tools, theory, and practice, European Journal of e-Practice. [Online]. vol. 4, pp. 4-18. Available: http://www.epractice.eu/files/ePracticeJournal-Volume-4 0. pdf.

Nurdin Nurdin

Rosemary Stockdale

Helana Scheepers 
[22] C. Codagnone and T. A. Undheim. (2008, August) Benchmarking e-government: Tools, theory, and practice, European Journal of e-Practice. [online]. vol. 4, pp. 4-18. Available: http://www.epractice.eu/files/ePracticeJournal-Volume-4 0 .pdf

[23] M. E. Cook. (2002, July) Making a Case for Local E-Government, in Center for Technology in Government. [Online]. Available: http://academic.udayton.edu/GrantNeeley/MPA\%20512/making a case.pdf

[24] A. Cordela, E-government: Towards the e-bureaucratic form?, Journal of Information Technology, vol. 22, no. 3, pp. 265-274, 2007

[25] A. Cordella and L. Willcocks, Outsourcing, bureaucracy and public value: Reappraising the notion of the "contract state", Government Information Quarterly, vol. 27, no. 1, pp. 82-88, 2010.

[26] D. Dada, The failure of e-government in developing countries: A literature review, The Electronic Journal of Information Systems in Developing Countries, vol. 26, no. 7, pp. 1-10, 2006.

[27] S. Dasgupta and B. Gupta, Espoused organizational culture traits and internet technology adoption, in Proceedings of the $15^{\text {th }}$ Americas Conference on Information Systems, San Fransisco, California, USA, pp. 1-8, 2009.

[28] S. S. Dawes and M. R. Nelson, Pool the Risk, Share the Benefits: Partnership in IT Innovation, in Technology Trendlines, Technology Success Stories from Today's Visionaries, J. Keyes, Ed. New York: Van Nostrand Reinhold, 1995, pp. 125-135.

[29] S. S. Dawes and T. A. Pardo, Building collaborative digital government systems, in Advances in digital government: Technology, human factors, and policy (W. J. Mclver and A. K. Elmagarmid, Eds). Boston: Kluwer Academic Publisher, 2002, pp. 259-273

[30] D. R. Denison. (2010, October) Denison Model: Consistency, Denison Consulting. [Online]. Available: http://www.denisonconsulting.com/advantage/researchModel/model/adaptability.aspx.

[31] D. R. Denison, S. Haaland, and P. Goelzer, Corporate culture and organizational effectiveness: Is there a similar pattern around the world?. Bingley: Emerald Group Publishing Limited, 2006.

[32] D. R. Denison and A. K. Mishra, Organizational culture and organizational effectiveness: A theory and some preliminary empirical evidence, University of Michigan, Ann Arbor, Michigan, MI 48109-1234, 1989.

[33] R. Dubin. Theory Building. New York: The Free Press, 1978.

[34] A. Dugdale, A. Daly, F. Papandera, and M. Maley, Accessing e-government: Challenges for citizens and organizations, International Review of Administrative Sciences, vol. 71, no. 1, pp. 109-118, 2005.

[35] Z. Ebrahim and Z. Irani, E-government adoption: Architecture and barriers, Business Process Management Journal, vol. 11, no. 5, pp. 589-611, 2005

[36] K. D. Edmiston, State and local e-government: Prospects and challenges, The American Review of Public Administration, vol. 33, no. 1, pp. 20-45, 2003.

[37] D. Evans and D. C. Yen, E-government: Evolving relationship of citizens and government, domestic, and international development, Government Information Quarterly, vol. 23, no. 2, pp. 207-235, 2006.

[38] R. R. Eynon and H. Margaret. (2007, November) Organizational solutions for overcoming barrier to egovernment, European Journal of e-Practice. [Online]. vol. 1, pp. 1-13. Available: http://www.epractice.eu/files/1.6.pdf.

[39] E. Eyob, E-government: Breaking the frontiers of inefficiencies in the public sector, Electronic Government, an International Journal, vol. 1, no. 1, pp. 107-114, 2004.

[40] G. T. Fairhurst and J. M. Jordan, Why are we here? Managing the meaning of an organizational mission statement, Journal of Applied Communication Research, vol. 25, no. 4, pp. 243-263, 1997.

[41] B. Farholt and F. Wahid, E-government challenge and the role of political leadership in Indonesia: The case of Sragen, in Proceedings of the $41^{\text {st }}$ Hawaii International Conference on System Sciences, Koloa, Kauai, Hawaii, USA, 2008, pp. 1-10.

[42] M. Ferguson, Local e-government in the United Kingdom, in Local Electronic Government, Helmut Druke, Ed. $\mathrm{NJ}$ : Routledge, 2004, pp. 136-170.

[43] E. Ferro and M. Sorrentino, Can inter-municipal collaboration help the diffusion of e-government in peripheral areas? Evidence from Italy, Government Information Quarterly, vol. 27, no. 1, pp. 17-25, 2010.

[44] R. G. Fichman and C. F. Kemerer, The assimilation of software process innovations: An organizational learning perspective, Management Science, vol. 43, no. 10, pp. 1345-1363, 1997.

[45] P. Foley. (2008, August). Realizing the transformation agenda: Enhancing citizens use of e-government, European Journal of e-Practice. [Online]. vol. 4, pp. 44-58, Available: http://www.epractice.eu/files/ePracticeJournal-Volume-4 0.pdf.

[46] M. J. Gallivan, Organizational adoption and assimilation of complex technological innovations: Development and application of a new framework, The Data Base for Advances in Information Systems, vol. 32, no. 3, pp. 51-85, 2001.

[47] K. W. Getao and A. N. Wausi, Organizational cultural dynamics and information and communication technology adaptation in a developing country: The case of the Kenyan joint university admission system, Information Technology for Development, vol. 15, no. 3, pp. 224-232, 2009.

[48] M. J. Ginzberg, An organizational contingencies view of accounting and information systems implementation, Accounting, Organizations and Society, vol. 5, no. 4, pp. 369-382, 1980.

[49] D. Griffin and E. Halpin, An exploratory evaluation of UK local e-government from an accountability perspective, The Electronic Journal of e-Government, vol. 3, no. 1, pp. 13-28, 2005.

[50] N. D. Harris, Intergovermental cooperation in the development and use of information systems, in Handbook of Public Infomation Systems, G. D. Garson, Ed. New York: Marcel Dekker, 2000, pp. 27-56. 
[51] J. Hartwick and H. Barki, Explaining the role of user participation in information system use, Management Science, vol. 40, no. 4, pp. 440-465, 1994.

[52] S.-A. Hazlett and F. Hill, E-government: The realities of using IT to transform the public sector, Managing Service Quality, vol. 13, no. 6, pp. 445-452, 2003.

[53] R. Heeks, E-government in Africa promise and practice, Information Polity, vol. 7, no. 2-3, pp. 97-114, 2002.

[54] R. Heeks, Most E-government for development projects fail: How can risks be reduced?, Institute for Development Policy and Management, University of Manchester, Manchester, UK, Paper No. 14, 2003.

[55] R. Heeks, E-government as a carrier of context, Journal of Public Policy, vol. 25, no. 1, pp. 51-74, 2005.

[56] R. Heeks, Reinventing Government in the Information Age: International Practice in IT-Enable Public Sectors Reform. London: Routledge, 1999.

[57] H. Z. Henriksen and K. V. Andersen, Electronic records management systems implementation in the Pakistan local governement, Records Management Journal, vol. 18, no. 1, pp. 40-52, 2008.

[58] A. T.-K. Ho, Reinventing local governments and the e-government initiative, Public Administration Review, vol. 62, no. 4, pp. 434-444, 2002.

[59] S. Y. Ho and K. W. K. Ho, Success of electronic government information portal: Technological issues or manageria issues?, Journal of E-Government, vol. 3, no. 2, pp. 53-74, 2006

[60] S. H. Holden, D. F. Norris, and P. D. Fletcher, Electronic government at local level: Progress to date and future issues, Public Performance and Management review, vol. 26, no. 4, pp. 325-344, 2003.

[61] J. Hwang and I. Syamsuddin, Failure of e-government implementation: A case study of south Sulawesi, in Proceeding of the $3^{\text {rd }}$ International Conference on Convergence and Hybrid Information Technology, Washington, DC, USA, vol. 2, 2008, pp. 952-960.

[62] J. H. K. Inkson, D. S. Pugh, and D. J. Hickson, Organization context and structure: An abbreviated replication, Administrative Science Quarterly, vol. 15, no. 3, pp. 318-329, 1970.

[63] Z. Irani, M. Themistocleous, and P. E. D. Love, The impact of enterprise application integration on information system lyfecycles, Information \& Management, vol. 41, no. 2, pp. 177-187, 2003.

[64] P. T. Jaeger and J. C. Bertot, Transparency and technological change: Ensuring equal and sustained public access to government information, Government Information Quarterly, vol. 27, no. 4, pp. 371-376, 2010.

[65] P. T. Jaeger and K. M. Thompson, E-government around the world: Lessons, challenges, and future directions, Government Information Quarterly, vol. 20, no. 4, pp. 389-394, 2003.

[66] S. L. Jarvenpaa and B. Ives, Executive involvement and participation in the management of information technology, MIS Quarterly, vol. 15, no. 2, pp. 205-227, 1991.

[67] S. Jones, Z. Irani, and A. M. Sharif, E-government evaluation: Reflection on three organizational case studies, in Proceeding of $40^{\text {th }}$ Hawaii International Conference on Systems Sciences, Waikoloa, Big Island, Hawaii, USA 2007, pp. 105.

[68] T. Jukic and M. Vintar, E-government: The state in Slovenian local self-government, Business, vol. 39, no. 3, pp. $176-181,2006$

[69] W. Kei and K. K. Wei, Successful e-government in Singapore, Communications of The ACM, vol. 47, no. 6, pp. 95-99, 2004.

[70] S. Kim and D. Kim, South Korean public officials' perception of values, failure, and consequences of failure in egovernment leadership, Public Performance and Management Review, vol. 26, no. 4, pp. 360-375, 2003.

[71] L. Komito, E-participation and governance: Widening the net, The Electronic Journal of e-Government, vol. 3, no. 1, pp. 39-48, 2005.

[72] R. Kumar and M. L. Best, Impact and sustainability of e-government services in developing countries: Lessons learned from Tamil Nadu, India, The Information Society, vol. 22, no. 1, pp. 1-12, 2006.

[73] M. Kunstelj and M. Vintar, Evaluating the progress of e-government development: A critical analysis, Information Polity, vol. 9, no. 3-4, pp. 131-148, 2004.

[74] W. Lam, Barriers to e-government integration, The Journal of Enterprise Information Management, vol. 18, no. 5, pp. 511-530, 2005.

[75] S. M. Lee, X. Tan, and S. Trimi, Current practices of leading e-government countries, Communication of the ACM, vol. 48, no. 10, pp. 99-104, 2005

[76] K. Lenk and R. Traounmuller, A framework for electronic government, in Proceedings at $11^{\text {th }}$ International Workshop on Database and Expert Systems Applications, IEEE Computer Society, London, UK, 2000, pp. 271277.

[77] B. Li, On the barriers to the development of e-government in China, in Proceedings of $7^{\text {th }}$ International Conference on Electronic Commerce, Xi'an, China, 2005, pp. 549-552

[78] S. C. Y. Luk, The impact of leadership and stakeholders on the success/failure of e-government service: Using the case study of e-stamping service in Hong Kong, Government Information Quarterly, vol. 26, no. 4, pp. 594$604,2009$.

[79] H. Margaret and P. Dunleavy, Cultural barriers to e-government, National Audit Office, London, HC 704-III, 2002.

[80] R. C. Mayer, J. H. Davis, and F. D. Schoorman, An integrative model of organizational trust, Academy of Management Review, vol. 20, no. 3, pp. 709-734, 1995.

[81] E. A. McDaniel, Facilitating cross-boundary leadership in emerging e-government leaders, Electronic Government, an International Journal, vol. 2, no. 1, pp. 1-10, 2005.

[82] P. McDermott, Building open government, Government Information Quarterly, vol. 27, no. 4, pp. 401-413, 2010

[83] J. Millard. (2008, August). E-government measurement for policy makers. European Journal of e-Practice. [Online]. vol. 4, pp. 19-32. Available: http://www.epractice.eu/files/ePractice-Journal-Volume-4 0.pdf. 
[84] R. B. Mitchell, Sources of transparency: Information system in international regimes, International Studies Quarterly, vol. 42, no. 1, pp. 109-130, 1998.

[85] M. J. Moon, The evolution of e-government among municipalities: Rhetoric or reality?, Public Administration Review, vol. 62, no. 4, pp. 424-433, 2002.

[86] M. J. Moon and D. F. Norris, Does managerial orientation matter? The adoption of reinventing government and e-government at the municipal level, Information Systems Journal, vol. 15, no. 1, pp. 43-60, 2005.

[87] B. Mukabeta Maumbe, V. Owei, and H. Alexander, Questioning the pace and pathway of e-government development in Africa: A case study of South Africa's Cape Gateway project, Government Information Quarterly, vol. 25, no. 4, pp. 757-777, 2008.

[88] J. A. Musso, C. Weare, and M. C. Hale, Designing web technologies for local governance reform: Good management or good democracy?, Political Communication, vol. 17, no. 1, pp. 1-19, 1999.

[89] V. Ndou, E-government for developing countries: Opportunities and challenges, Electronic Journal of Information Systems in Developing Companies, vol. 18, no. 1, pp. 1-24, 2004.

[90] I. Netchaeva, E-government and e-democracy: A comparison of opportunities in the north and south, Gezette: The International Journal for Communication Studies, vol. 64, no. 5, pp. 467-477, 2002.

[91] D. F. Norris and M. J. Moon, Advancing e-government at the grassroots: Tortoise or hare?, Public Administration Review, vol. 65, no. 1, pp. 64-75, 2005

[92] A.-M. Oostveen and P.-v.-d. Besselaar, From small scale to large scale user participation: A case study of participatory design in e-government systems, in Proceedings Participatory Design Conference, Toronto, Canada, 2004, pp. 173-182.

[93] A. Rand, The nature of government, in The Virtue of Selfishness, A. Rand, Ed. New York: Penguin Group, 1964, pp. 102-109.

[94] C. G. Reddick and H. A. Frank, The perceived impacts of e-government on U.S. cities: A survey of Florida and Texas City managers, Government Information Quarterly, vol. 24, no. 3, pp. 576-594, 2007.

[95] W. R. Rose and G. G. Grant, Critical issues pertaining to the planning and implementation of e-government initiatives, Government Information Quarterly, vol. 27, no. 1, pp. 26-33, 2010.

[96] S. Rowlinson, Matrix organization structure, culture and commitment: A Hong Kong public sector case study of change, Construction Management and Economics, vol. 19, no. 7, pp. 669-673, 2001.

[97] J. Roy, The relational dynamics of e-governance: A case study of the city of Ottawa, Public Performance and Management Review, vol. 26, no. 4, pp. 391-403, 2003.

[98] G. P. Sahu and M. P. Gupta, Users' acceptance of e-government: A study of Indian central excise, International Journal of Electronic Government Research vol. 3, no. 3, pp. 1-21, 2007

[99] L. K. Schaper and G. P. Pervan, Developing a model technology acceptance within the Australian healthcare sector, in Proceedings the 10th Pacific Asia Conference on Information Systems, Mandarin Oriental, Kuala Lumpur, Malaysia, pp. 835-847, 2006.

[100] T. Schuppan, E-government in developing countries: Experiences from sub-Saharan Africa, Government Information Quarterly, vol. 26, no. 1, pp. 118-127, 2009.

[101] M. Scott, W. Golden, and M. Hughes, Implementation strategies for e-government: A stakeholder analysis approach, in Proceedings of the $13^{\text {th }}$ European Conference on Information Systems, Turku, Finland, June 1416, 2004, pp. 1-14.

[102] H. Sharifi and B. Zarei, An adaptive approach for implementing e-government in I.R. Iran, Journal of Government Information, vol. 30, no. 5-6, pp. 600-619, 2004.

[103]M. Sharifi and A. Manian, The study of the success indicators for pre-implementation activities of Iran's egovernment development projects, Government Information Quarterly, vol. 27, no. 1, pp. 63-69, 2010.

[104]E. Shepherd, A. Stevenson, and A. Flinn, Information governance, records management, and freedom of information: A study of local government authorities in England, Government Information Quarterly, vol. 27, no. 4, pp. 337-345, 2010.

[105] S. C. Srivastava and T. S. H. Teo, Electronic government as a guided evolution in Singapore: Vision for the world in the $21^{\text {st }}$ century, in Proceedings Academy of Management, Honolulu, Hawaii, USA, August 5-10, 2005, pp. 1-6.

[106] L. Stojanovic, N. Tojanovic, and D. Apostolou, Change management in e-government: Onto Gov case study, Electronic Government, vol. 3, no. 1, pp. 74-92, 2006.

[107] C. W. Tan, S. L. Pan, and E. T. K. Lim, Managing stakeholder interest in e-government implementation: Lesson learned from a Singapore e-government project, Journal of Global Information Management, vol. 13, no. 1, pp. 31-53, 2005.

[108]T. S. H. Teo and J. S. K. Ang, An examination of major IS planning problems, International Journal of Information Management, vol. 21, no. 6, pp. 457-470, 2001.

[109]R. Titah and H. Barki, E-government adoption and acceptance: A literature review, Electronic Government, an International Journal, vol. 2, no. 3, pp. 23-57, 2006.

[110]R. Traunmüller and M. Wimmer, E-government at a decisive moment: Sketching a roadmap to excellence, in Electronic Government. vol. 2739, R. Traunmüller, Ed. Heidelberg: Springer Berlin, 2003, pp. 1073-1073.

[111] United-Nations, UN E-Government Survey 2008: From E-Government to Connect Governance, Department of Economic and Social Affairs, New York, USA, ST/ESA/PAD/SER.E/112, 2008.

[112] C. Vassilakis, G. Lepouras, J. Fraser, S. Haston, and P. Georgiadis, Barriers to electronic service development, E-Service Journal, vol. 4, no. 1, pp. 46-66, 2005

[113]D. Vriens and J. Achterberg, Planning e-local government, Information Systems Management, vol. 21, no. 1, pp. $45-57,2004$

Nurdin Nurdin Rosemary Stockdale Helana Scheepers 
[114]E. J. Wallach, Individuals and organizations: The cultural match, Training \& Development Journal, vol. 37, no. 2, pp. 29-36, 1983.

[115] M. Warkentin, D. Gefen, P. A. Pavlou, and G. M. Rose, Encouraging citizen adoption of e-government by building trust, Electronic Markets, vol. 12, no. 3, pp. 157-162, 2002.

[116]P. P. Wauters and B. Lorincz. (2008, August). User satisfaction and administrative simplification within the perspective of e-government impact: Two faces of the same coin?, European Journal of e-Practice. [Online]. vol. 4, pp. 59-66. Available: http://www.epractice.eu/files/ePractice-Journal-Volume-4 0.pdf.

[117] V. Weerakkody, Y. K. Dwivedi, L. Brooks, and M. D. Williams, E-government implementation in Zambia: Contributing factors, Electronic Government, an International Journal, vol. 4, no. 4, pp. 484-508, 2007.

[118]C. C. William, Trust diffusion: The effect of interpersonal trust on structure, function and organizational transparency, Business \& Society, vol. 44, no. 3, pp. 357-368, 2005.

[119] M. Wimmer, H. Scholl, E. Ferro, and M. Sorrentino, Does the answer to e-government lie in inter-municipal collaboration? An exploratory Italian case study, in Proceedings at $7^{\text {th }}$ International Conference on Electronic Government, Turin, Italy, 2008, pp. 1-12.

[120] M. M. Wimmer, R. Traunmüller, Å. Grönlund, K. Andersen, A. C. B. Garcia, C. Maciel, and F. B. Pinto, A quality inspection method to evaluate e-government sites, in Proceedings at $4^{\text {th }}$ International Conference on Electronic Government, Copenhagen, Denmark, 2005, pp. 198-209.

[121] C. Yu-Che and J. Gant, Transforming local e-government services: the use of application service providers, Government Information Quarterly, vol. 18, no. 4, pp. 343-355, 2001.

[122] J. Zhang, S. S. Dawes, and J. Sarkis, Exploring stakeholders' expectations of the benefits of e-government knowledge sharing, The Journal of Enterprise Information Management, vol. 18, no. 5, pp. 548-567, 2005. 